\title{
Identifikasi Telur Cacing Soil Transmitted Helminths pada Sayuran Selada (Lactuca Sativa) yang Dijual oleh Pedagang Makanan di Sepanjang Jalan Perintis Kemerdekaan Kota Padang
}

Nashiha Alsakina ${ }^{1}$, Adrial $^{2}$, Nita Afriani $^{3}$

\begin{abstract}
Abstrak
Soil Transmitted Helminthiasis atau penyakit kecacingan adalah istilah yang merujuk kepada sekelompok penyakit akibat infeksi cacing Soil Transmitted Helminths (STH). Manusia dapat terinfeksi apabila tertelan telur STH yang infektif. Jalur masuk telur STH salah satunya melalui sayur selada (Lactuca sativa) yang dimakan mentah. Sayur selada (Lactuca sativa) ditanam pada tanah yang lembab, gembur dan diberi pupuk kandang bahkan disiram dengan air septic tank dan air limbah ternak agar dapat tumbuh optimal. Proses ini memungkinkkan kontaminasi telur STH pada sayuran selada. Tujuan penelitian ini adalah untuk mengidentifikasi telur STH pada sayuran selada (Lactuca sativa) yang dijual oleh pedagang makanan di sepanjang Jalan Perintis Kemerdekaan Kota Padang. Jenis penelitian ini adalah studi deskriptif dengan teknik pemeriksaan sedimentasi. Sampel diambil dari seluruh pedagang makanan yang menjual selada di sepanjang Jalan Perintis Kemerdekaan Kota Padang. Pengambilan sampel dilakukan sebanyak tiga kali pengambilan selama tiga minggu. Hasil pemeriksaan sampel selada dinyatakan positif sebanyak 38, 1\%, dengan kontaminasi terbanyak disebabkan oleh telur Ascaris sp 34, 1\% lalu telur Trichuris sp dan cacing tambang masing-masing 1,58 \%. Simpulan penelitian ini adalah terdapat kontaminasi telur STH pada sayuran selada yang dijual oleh pedagang makanan di sepanjang Jalan Perintis Kemerdekaan Kota Padang.
\end{abstract}

Kata kunci: kecacingan, Ascaris sp, Trichuris sp, cacing tambang, sayuran selada

\section{Abstract}

Soil Transmitted Helminthiasis is a term that refers to a group of diseases caused by Soil Transmitted Helminths (STH) infection. People are infected with STH when the infective eggs are ingested. One of the egg entrance is by eating unwashed lettuce (Lactuca sativa). This lettuce were planted in moist and loose soil, manure, even watered with septic tank and wastewater to grow optimally. This process increase the possibility of STH' egg contamination on the lettuce (Latuca sativa). The objective of this study was to identify STH's egg on lettuce that was sold by food sellers along Perintis Kemerdekaan Street Padang. This study was a descriptive study and examined using sedimentation technique. Samples were obtained from all of the food sellers along Perintis Kemerdekaan Street Padang. Sampling was performed three times in three weeks. Lettuce samples tested positive for $38.1 \%$, with the highest contamination caused by the eggs of Ascaris sp 34.1\%, eggs of Trichuris sp and hookworm $1.58 \%$ respectively. It can be concluded that there is contamination of STH eggs on lettuce sold by food sellers along Perintis Kemerdekaan Street Padang.

Keywords: soil transmitted helminthiasis, Ascaris sp, Trichuris sp, hookworm, lettuce

Affiliasi penulis: 1. Prodi Kedokteran Fakultas Kedokteran Universitas Andalas Padang (FK Unand), 2. Bagian Parasitologi FK Unand, 3. Bagian Histologi FK Unand
Korespondensi: Nashiha Alsakina

Email : nashihalsakina@gmail.com Telp: 01266735500. 


\section{PENDAHULUAN}

Soil Transmitted Helminths (STH) merupakan cacing golongan nematoda usus yang menginfeksi manusia yang menelan telurnya melalui rute fekal oral. Cacing ini terdiri dari beberapa jenis yaitu Ascaris lumbricoides, Trichuris trichiura, Necator americanus dan Ancylostoma duodenale serta Strongyloides stercoralis. ${ }^{1}$ Penyakit kecacingan dapat menyebabkan seseorang mengalami anemia defisiensi besi, kekurangan mikronutrien khususnya vitamin $\mathrm{A}$, pertumbuhan terhambat, malnutrisi dan diare kronik serta penurunan produktifitas pekerjaan sebanyak $40 \%{ }^{2}$

Saat ini penyakit kecacingan telah menginfeksi lebih dari $24 \%$ penduduk dunia dan tersebar di Negara tropis dan subtropis termasuk di Asia Tenggara. ${ }^{3}$ Prevalensi penyakit kecacingan di Indonesia pun masih tinggi yaitu mencapai $20-86 \%$ bervariasi di masing-masing daerah dengan rata-rata $30 \%{ }^{4}$ Penyakit kecacingan masih menjadi beban di Kota Padang, terlihat dari data DKK Padang bahwa selalu terjadi peningkatan jumlah kasus dari tahun 2012 hingga tahun 2014. Puskesmas Andalas dengan salah satu wilayah kerjanya adalah Kelurahan Jati selalu menjadi lima besar wilayah dengan angka kecacingan tertinggi serta terjadi peningkatan posisi, pada tahun 2013 posisi ke 5, tahun 2014 posisi ke 4 dan tahun 2015 posisi ke $2 .^{5}$

Peningkatan jumlah penyakit infeksi beberapa tahun terakhir berhubungan dengan mengonsumsi buah dan sayuran segar. ${ }^{6}$ Sayuran yang langsung dimakan berisiko untuk dicemari oleh berbagai jenis parasit selama penanaman, pemanenan dan pemasaran serta memiliki potensi untuk penularan infeksi kepada manusia. ${ }^{7}$

Kelurahan Jati khususnya Jalan Perintis Kemerdekaan merupakan daerah yang dikelilingi sentra pendidikan, perkantoran juga kos-kosan, sehingga menjadi tempat yang dipilih oleh pedagang makanan untuk berjualan disepanjang pinggir jalan. Hal ini didukung oleh suatu penelitian bahwa penentuan lokasi yang dipilih oleh pedagang untuk berjualan salah satunya adalah terdapat akumulasi orang-orang yang melakukan aktivitas rutin disekitar area tersebut. ${ }^{8}$
Berdasarkan latar belakang diatas dan observasi pendahuluan yang dilakukan di Jalan Perintis Kemerdekaan Kelurahan Jati Kecamatan Padang Timur Kota Padang terdapat banyak pedagang yang menjual menu makanan dengan sayur selada sebagai Ialapan. Selada yang dimakan tanpa dimasak masih memungkinkan menginfeksi konsumennya. Beban penyakit akibat infeksi STH pada selada dikaitkan dengan dampak kronis yang membahayakan kesehatan serta kualitas hidup. Mengingat hal itu maka perlu dilakukan penelitian yang menggambarkan kontaminasi telur STH sehingga dapat dijadikan sebagai sumber promosi kesehatan untuk upaya pencegahan penyakit kecacingan.

\section{METODE}

Jenis penelitian ini adalah studi deskriptif yang dilaksanakan pada bulan November 2016 sampai Januari 2017 di Laboratorium Parasitologi Fakultas Kedokteran Universitas Andalas. Populasi penelitian ini adalah semua selada yang dijual dan disajikan oleh pedagang makanan sepanjang Jalan Perintis Kemerdekaan Kota Padang. Sampel pada penelitian ini adalah dua helai selada yang dijual oleh pedagang makanan tersebut dengan kriteria inklusi yaitu selada mentah yang masih segar, selada yang disajikan, selada daun atau selada keriting serta bukan selada yang busuk ataupun yang dicuci dengan teknik blansir. Sampel diperoleh dari 21 pedagang makanan dengan teknik total sampling sebanyak tiga kali pengambilan dalam tiga minggu dan didapat total 63 sampel.

Prosedur identifikasi telur STH pada selada dilakukan dengan teknik sedimentasi, sehingga telur yang disentrifugasi terendapkan. Hasil pemeriksaan divalidasi sesuai dengan buku Atlas Helmintologi dan Protozoologi Kedokteran edisi ke 4 Chiodini, kemudian dituangkan kedalam tabel distribusi frekuensi per pedagang makanan.

\section{HASIL}

Lima belas dari dua puluh satu pedagang makanan merupakan pedagang kaki lima yang menggunakan fasilitas umum atau trotoar pinggir jalan dan dilalui oleh berbagai kendaraan bermotor sebagai 
tempat berjualan dan menggunakan gerobak semi permanen serta tenda terbuka sebagai tempat untuk berjualan. Sebagian besar pedagang makanan memperoleh selada dari pasar tradisional (Pasar Alai dan Pasar Raya) dan satu pedagang memperoleh selada langsung dari Alahan Panjang. Sebagian besar dari mereka juga tidak mencuci selada dengan air mengalir. Pedagang makanan hanya merendam dan mengucek-ngucek selada. Pada saat penyajian selada, pedagang makanan menyajikan selada tanpa menggunakan sendok maupun sarung tangan.

\section{Hasil Identifikasi}

Pemeriksaan yang dilakukan terhadap pedagang makanan yang menjual selada (Lactuca sativa) di Jalan Perintis Kemerdekaan Kota Padang untuk mengidentifikasi telur cacing Soil Transmitted Helminths (STH) menunjukkan hasil sebagai berikut.

Tabel 1. Hasil identifikasi Telur STH pada selada

\begin{tabular}{ccc}
\hline Hasil Pemeriksaan & Frekuensi & $\%$ \\
\hline+ & 24 & 38,1 \\
- & 39 & 61,9 \\
\hline Jumlah & 63 & 100 \\
\hline
\end{tabular}

Berdasarkan Tabel 1, terlihat kontaminasi telur STH terhadap 63 sampel sayuran selada yang diperoleh dari 21 pedagang di sepanjang Jalan Perintis Kemerdekaan Kota Padang menunjukkan $38,1 \%$ selada positif terkontaminasi telur STH.

Tabel 2. Jenis STH yang teridentifikasi pada Selada

\begin{tabular}{lcc}
\hline \multicolumn{1}{c}{ Jenis } & Frekuensi & $\%$ \\
\hline Ascaris $s p$ & 22 & 34,92 \\
Trichuris $s p$ & 1 & 1,58 \\
Cacing Tambang & 1 & 1,58 \\
\hline Jumlah & 24 & 38,1
\end{tabular}

Berdasarkan data pada Tabel 2 diatas, jenis telur STH yang mengontaminasi sayuran selada yang dijual oleh pedagang makanan di sepanjang Jalan Perintis Kemerdekaan Kota Padang adalah telur Ascaris sp dengan frekuensi 22 (34,92 \%), telur Trichuris $s p$ dengan frekuensi 1 (1,58 \%), dan telur cacing tambang dengan frekuensi 1 (1,58\%).

\section{PEMBAHASAN}

Pemeriksaan yang telah dilakukan terhadap 21 pedagang makanan yang menjual selada di sepanjang Jalan Perintis Kemerdekaan Kota Padang menunjukkan 38,1 \% selada positif terkontaminasi telur Soil Transmitted Helminths (STH). Hasil pada penelitian ini lebih rendah dibandingkan penelitian yang dilakukan Asihka et al pada tahun 2013 terhadap sayuran selada yang dijual pedagang di pasar tradisional dan di pasar modern yang ditemukan masing-masing $40 \%$ dan $70 \%$, namun lebih tinggi dibandingkan oleh penelitian yang dilakukan Wardhana et al pada tahun 2013 terhadap sayuran kubis ditemukan sebanyak 26, 19\%. ${ }^{9,10}$ Perbedaan hasil ini mungkin disebabkan faktor sayuran selada yang didapat dari pasar tidak dicuci sama sekali dan langsung diperiksa, sementara pada sayuran kubis bisa disebabkan bentuk sayuran kubis yang tidak terlalu berlekuk seperti sayuran selada.

Peluang kontaminasi telur STH pada selada bisa disebabkan berbagai hal, diantaranya pada saat pembudidayaan selada, selada disiram dengan air limbah, septic tank atau limbah ternak. ${ }^{11}$ Petani selada yang menggunakan limbah ternak atau air septic tank untuk menyiram sayuran selada pada saat pembudidayaan memungkinkan selada terkontaminasi oleh feses yang mengandung telur STH.

Hampir seluruh pedagang makanan di sepanjang Jalan Perintis Kemerdekaan Kota Padang memperoleh selada dari pasar tradisional (Pasar Raya dan Pasar Alai) dan seorang pedagang memperoleh selada yang dikirim langsung dari Alahan Panjang. Pedagang selada di Pasar Tradisional di Kota Padang meletakkan selada di baki sayur, di atas meja, atau di dalam karung maupun kantong plastik besar, bahkan tidak jarang terletak sembarangan yang langsung bersentuhan dengan tanah, sehingga memungkinkan risiko kontaminasi dari pasar.

Pedagang makanan yang menjual selada di sepanjang Jalan Perintis Kemerdekaan Kota Padang sebagian besar merupakan pedagang kaki lima. Mereka menggunakan gerobak semi permanen dan tenda terbuka sebagai bangunan untuk berjualan. Makanan yang dibiarkan terbuka memungkinkan kontaminasi dari debu jalanan. 
Peluang kontaminasi telur STH bisa dipengaruhi oleh tingkat kebersihan dari pengolah makanan itu sendiri maupun cara mereka mengolah makanan. Hasil wawancara dan pengamatan tersebut, pedagang makanan mencuci daun selada hanya dengan merendam lalu mengucek-ngucek di dalam ember. Telur STH mungkin saja sedikit terlepas dari daun selada namun tetap berada di dalam ember dan tetap menggenang. Pada penelitian ini juga ditemukan seorang pedagang makanan yang mencuci selada dengan air mengalir dan ternyata pada pemeriksaan memang tidak ditemukan sama sekali telur cacing mengontaminasi selada yang dijualnya. Selain itu perlu diperhatikan saat penyajian selada pedagang juga tidak menggunakan sarung tangan ataupun sendok, sehingga memungkinkan risiko kontaminasi telur STH.

Telur dari cacing Ascaris sp mendominasi kontaminasi terhadap sayuran selada. Hal ini bisa disebabkan oleh daya tahan telur spesies Ascaris terhadap asam kuat, basa kuat, oksidan, reduktan, dan agen aktif permukaan. ${ }^{12}$ Prevalensi kontaminasi telur A.lumbricoides juga bisa disebabkan oleh produksi telur yang sangat tinggi. Seekor cacing A.lumbricoides betina dapat memproduksi hingga 200.000 telur per hari dibanding T.trichiura yang hanya 3000-5000 per hari, N.americanus 9000-10.000 per hari dan A.duodenale 25.000-30.000 per hari. ${ }^{13}$

Pada penelitian ini telur cacing tambang ditemukan dalam jumlah sedikit, mungkin disebabkan oleh siklus kehidupan cacing tambang yang berbeda. Telur cacing tambang yang keluar bersama feses setelah 1-2 hari akan menetas menjadi larva, sehingga tidak ditemukan lagi di tanah. ${ }^{14}$

Selada yang terkontaminasi telur cacing STH dapat mengakibatkan orang yang memakannya menderita penyakit kecacingan. Gejala penyakit yang muncul tergantung jenis STH yang mengontaminasi selada yang dimakan. Orang yang memakan selada dengan telur $A$. lumbricoides infektif dapat mengalami gangguan pada paru berupa batuk disertai demam, eosinofilia, adanya infiltrat di paru serta dapat mengalami obstruksi pada usus dan malabsorbsi. ${ }^{15}$ Apabila seseorang memakan sayuran selada dengan telur cacing $A$. lumbricoides tidak infektif maka orang tersebut tidak akan terinfeksi sama sekali. Seseorang yang memakan selada yang terkontaminasi telur $T$. trichiura dapat mengalami diare berdarah, mual, muntah dan bahkan dapat mengakibatkan mukosa rektum prolaps. ${ }^{16}$

Sesuai dengan Tabel 2 juga ditemukan telur cacing tambang dengan presentasi $1,58 \%$ pada sayuran selada. Hal ini sebenarnya tidak berbahaya karena bentuk cacing tambang yang ditemukan yaitu pada stadium telur dan bukan merupakan bentuk yang infektif. Sesuai dengan siklus hidupnya cacing tambang hanya dapat menginfeksi jika larva filariform menembus kulit atau apabila seseorang tertelan larva filariform dari cacing tambang jenis A.duodenale. Walaupun stadium telur cacing tambang bukanlah merupakan bentuk infektif, namun jika suatu waktu telur tersebut jatuh dari selada ke tanah dan berkembang menjadi larva filariform makan dapat menginfeksi manusia. Gejala yang ditimbulkan apabila terinfeksi dapat berupa mual, muntah, nyeri perut, diare bahkan anemia akibat penghisapan darah oleh cacing. ${ }^{17}$

Pemeriksaan telur cacing STH dalam penelitian ini memiliki keterbatasan. Telur Trichuris $s p$ yang ditemukan pada pemeriksaan ini tidak dapat dibedakan apakah ini jenis telur Trichuris trichiura yang menginfeksi manusia atau Trichuris suis dan Trichuris pulvis menginfeksi hewan karena morfologi telurnya yang sangat mirip (CFSPH). ${ }^{18}$ Telur Ascaris $s p$ yang ditemukan bisa jadi merupakan telur Ascaris suum, karena telur A.lumbricoides memiliki morfologi yang sangat identik dengan telur Ascaris suum yang hanya menginfeksi hewan. Morfologi yang mirip ini mengakibatkan sulitnya membedakan kedua jenis telur tersebut saat diperiksa di bawah mikroskop. ${ }^{19}$

\section{SIMPULAN}

Terdapat kontaminasi telur STH pada selada yang dijual oleh pedagang makanan sepanjang Jalan Perintis Kemerdekaan Kota Padang sebanyak 38,1\%.

Jenis telur yang mengontaminasi adalah telur Ascaris sp (34,92\%), Trichuris sp (1,58\%) dan telur cacing tambang $(1,58 \%)$. 


\section{DAFTAR PUSTAKA}

1. Natadisastra D, Agoes R. Parasitologi kedokteran: ditinjau dari tubuh yang diserang. Jakarta: EGC; 2009.

2. World Health Organization (WHO). Working to overcome the global impact of neglected tropical disease : First WHO report on neglected tropical disease. Nonserial Publication. WHO. 2016.

3. WHO. Soil transmitted helminth infections. Global distribution and prevalence. (serial online) 2016 (diunduh April 2016). Tersedia dari: http://www. who.int/mediacentre/factsheets/fs366/en/

4. Direktorat Jenderal Pengendalian Penyakit (PP) dan Penyehatan Lingkungan (PL). Rencana aksi program pegendalian penyakit dan penyehat lingkungan tahun 2015-2019. Jakarta: Direktorat Jendral PP dan PL; 2015.

5. Dinas Kesehatan Kota Padang. Rekap total laporan bulanan data kesakitan tahun 2012-2015. Padang: DKK Padang; 2015.

6. Abougrain AK, Nahaisi MH, Madi NS, Saied MM, Ghenghesh KS. Parasitological contamination in salad vegetables in Tripoli-Libya. $\mathrm{J}$ Food Cont. 2009; 21:760-2.

7. Ebrahimzadeh A, Jamshidi A, Mohammad S. The parasitic contamination of raw vegetables consumed in Zaedan. Iran. J Health Scope. 2013; 1(4): 205-9.

8. Widjajanti R. Karakteristik aktivitas pedagang kaki lima di ruang kota (Studi kasus: kawasan pendidikan Tembalang, Kota Semarang). Jurnal Pembangunan Wilayah \& Kota. 2012;8(4):412-24.

9. Asihka V, Nurhayati, Gayatri. Distribusi frekuensi Soil Transmitted Helminths pada sayuran selada (Lactuca sativa) yang dijual di pasar tradisional dan pasar modern di Kota Padang. Jurnal Kesehatan Andalas. 2013;3(3):480-5.
10. Wardhana KP, Kurniawan B, Mustofa S. Identifikasi Soil Transmitted Helminths pada lalapan kubis (Brassica oleracea) di warungwarung makan Universitas Lampung. Medical Journal of Lampung University. 2014;3(3):86-95.

11. Pracaya. Bertanam sayuran organic. Edisi revisi. Jakarta: Penebar Swadaya; 2011.

12. Oh KS, Kim GT, Ahn KS, Shin SS. Effects of disinfectants on larval development of Ascaris sum eggs. Korean J Parasitol. 2016:54(1):103-7.

13. Bethony J, Brooker S, Albonico M, Geiger SM, Loukas A, Diemert $\mathrm{T}$, et al. Soil-transmitted helminth onfections: ascariasis, trichuriasis, and hookworm. Lancet. 2006; 367(9521):1521-32.

14. Centers for Disease Control and Prevention (CDC). Parasites. (serial online) 2016 (diunduh Desember 2016). Tersedia dari: http://www.cdc.gov/ parasites/ascariasis/index.html

15. Gandahusada S, Illatude HD, Pribadi W. Parasitologi kedokteran. Edisi ke-3. Jakarta: Balai Penerbit Fakultas Kedokteran Universitas Indonesia; 2002.

16. Soedarto. Buku ajar parasitologi kedokteran. Surabaya: Sagung Set ; 2011.

17. Widyono. Penyakit tropis: Epidemiologi, penularan, pencegahan \& pemberantasannya. Edisi ke-2. Semarang: Erlangga; 2011.

18. Control Food Security \& Public Health. Trichuriasis. (serial online) 2017 (diunduh Februari 2017). Tersedia dari: http://www.cfsph.iastate.edu/ Factsheets/pdfs/trichuriasis. pdf

19. Leles D, Gardner SL, Reinhars K, Iniguez A, Araujo A. Are Ascaris lumbricoides and Ascaris suum a single species?. Parasites \& Vector. 2012; 5 (42). 